\title{
Perancangan Aplikasi Pemrograman Diagram Alir untuk Trainer Pembelajaran Robotika Berbasis Android
}

\author{
Deddy Susilo ${ }^{1}$ Gunawan Dewantoro ${ }^{2}$, Teuku Danny Ramdani ${ }^{3}$ \\ Program Studi Teknik Elektro, \\ Fakultas Teknik Elektronika dan Komputer, \\ Universitas Kristen Satya Wacana, Salatiga \\ 1deddy.susilo@staff.uksw.edu, ${ }^{2}$ gunawan.dewantoro@staff.uksw.edu \\ 3612010041@student.uksw.edu
}

\begin{abstract}
Ringkasan
Sistem pembelajaran interaktif yang dibangun bertujuan sebagai trainer pembelajaran robotika untuk siswa-siswi SD (Sekolah Dasar) sampai dengan SMA (Sekolah Menengah Atas). Trainer tersebut akan memperkenalkan logika dari cara kerja robot dengan menggunakan diagram alir. Siswa-siswi akan mempelajari cara untuk merancang logika robot bekerja yang terdiri dari perulangan, percabangan, dan beberapa instruksi dasar. Trainer pembelajaran robotika dibangun dengan komponen utama yaitu : sensor jarak, modul bluetooth, driver motor, mikrokontroler dan smartphone. Perangkat lunak yang digunakan untuk memberikan instruksi kepada robot tersebut berasal dari smartphone android yang di dalamnya sudah di instal aplikasi trainer robotika dengan format extension apk. Hasil pengujian menunjukan bahwa trainer robotika ini dapat menjalankan instruksi yang diberikan oleh smartphone android. Robot dapat di instruksikan untuk berjalan maju, kanan, kiri, mundur, dan mendeteksi rintangan. Tingkat keberhasilan dari Trainer Robotika yang diuji adalah mencapai $90 \%$, dikarenakan robot memiliki kelemahan jika berjalan di permukaan yang licin. Pada saat robot berjalan di permukaan yang licin terjadi perbedaan antara jarak yang di instruksikan dengan jarak robot saat berjalan. Bahasa pemrograman yang digunakan adalah bahasa $\mathrm{C}$ untuk mikrokontroler dan untuk aplikasi pada Android menggunakan bahasa pemrograman Java.
\end{abstract}

Kata kunci: trainer robotika, diagram alir, pemrograman android.

\section{Pendahuluan}

Pada zaman sekarang perkembangan teknologi berkembang dengan pesat, di mana di setiap aspek kehidupan tidak jauh dengan teknologi. Salah satu teknologi yang sedang berkembang saat ini adalah robotika. Robot dalam hal ini adalah robot yang dapat mempermudah pekerjaan manusia. Dengan semakin pesatnya perkembangan robot di zaman sekarang mendorong kepada siswa dan sisiwi sekolah dasar sampai dengan sekolah menengah atas untuk mempelajari tentang robotika. Semakin banyaknya siswasiswi yang menaruh minat dalam mempelajari robotika di beberapa sekolah sudah menyediakan kelas ekstrakurikuler robotika di mana di kelas tersebut para siswa-siswi belajar teori-teori tentang robotika, pengenalan tentang komponen robotika dan para siswa-siswi belajar untuk merancang robot sederhana. Robot yang dipelajari dan sudah dirancang sebelumnya adalah robot pengikut lintasan dan robot Sumo (Robot yang 
dikendalikan oleh remote). Pada saat ini dibutuhkan sebuah alat trainer robotika yang digunakan untuk pembelajaran robotika untuk siswa-siswi tingkat sekolah dasar sampai sekolah menengah Atas dengan tujuan para siswa-siswi tersebut akan mengerti logika cara kerja robot.

\section{Kajian Pustaka}

Pada referensi [1] dijelaskan tentang perancangan robot dengan cara membangun suatu perangkat lunak berbasis diagram alir menggunakan simbol-simbol dari tiap blok diagram yang memiliki perintah untuk menggerakkan robot. Perintah ini berupa source code yang dikirim dari PC ke mikrokontroler AT89S52. Mikrokontroler menampilkan simulasi berdasarkan diagram alir yang dibuat pada perangkat lunak. Simulasi output dari perangkat lunak ditunjukkan pada port 0 mikrokontroler, sedangkan simulasi input dari perangkat lunak ditunjukkan pada port 1 mikrokontroler. Simulasi output yang dihasilkan sesuai dengan diagram alir pada perangkat lunak, yang dibuat dapat digunakan untuk mengontrol robot. Perangkat tambahan yang diperlukan adalah driver, ADC (Analog to Digital Converter), DAC (Digital to Analog Converter).

\section{Perancangan}

Pada bagian ini akan dijelaskan mengenai perancangan dari perangkat keras, serta perangkat lunak dari algoritma robot.

\subsection{Perancangan Perangkat Keras}

Pada bagian ini akan dijelaskan mengenai perancangan perangkat keras. Perancangan perangkat keras yang akan dijelaskan meliputi sistem kontrol, konstruksi robot, dan perangkat keras elektronik.

\subsubsection{Sistem Kontrol}

Sistem kontrol pada robot terdiri dari 2 bagian yaitu kontrol utama dan kontrol akuator.

1. Kontrol Utama

Kontrol utama pada robot terdiri dari sebuah smartphone [2] dan mikrokontroler. Pada smartphone akan memberikan instruksi pergerakan robot dengan menggunakan diagram alir. Data dari smartphone akan dikirimkan melalui komunikasi bluetooth. Kemudian pada mikrokontroler terdiri dari modul bluetooth yang akan menerima instruksi dari smartphone tersebut.

2. Kontrol Aktuator Robot

Kontrol akuator pada robot ini adalah driver motor L298[3], SRF-05 dan photointerrupter. Setelah data yang dikirimkan oleh smartphone diterima oleh mikrokontroler maka mikrokontroler akan memberikan instruksi pada driver motor L298, SRF-05 dan photointerrupter. Setelah itu robot akan berjalan sesuai dengan diagram alir yang sudah dibuat pada smartphone. 


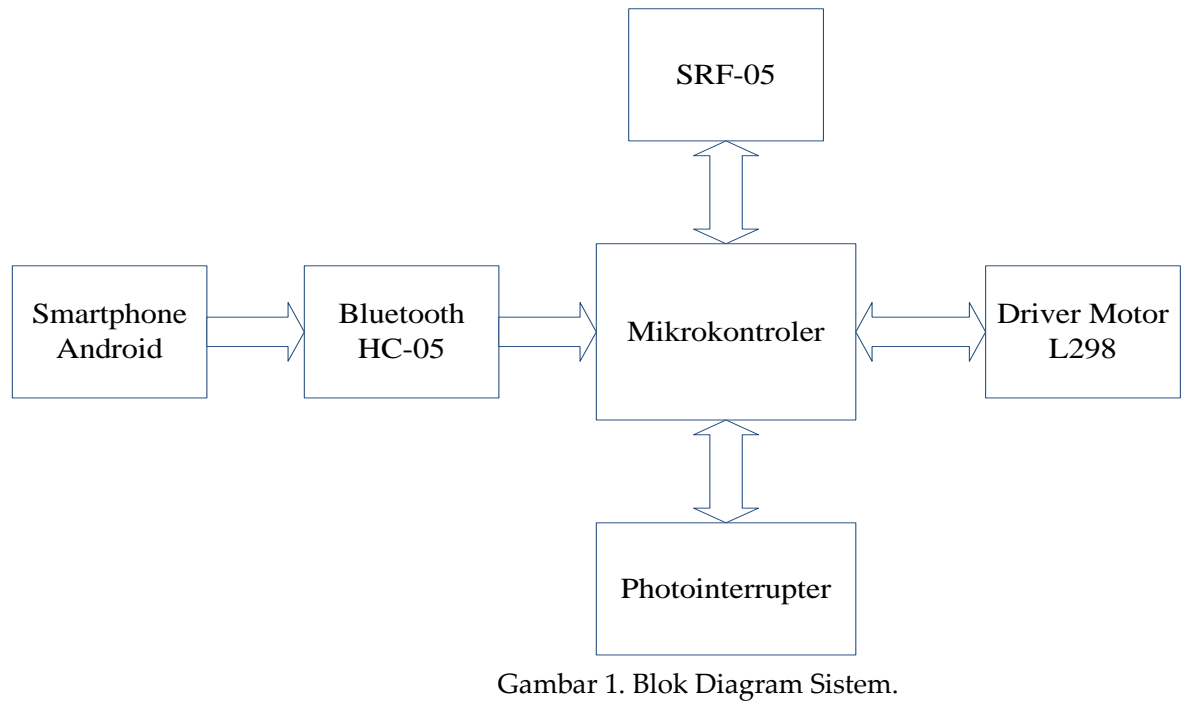

\subsubsection{Konstruksi Robot}

Robot ini menggunakan perpaduan bahan antara plastik dan akrilik untuk bodi sasisnya. Perpaduan bahan ini dimaksudkan agar robot memiliki bobot yang ringan sehingga memiliki keseimbangan yang baik. Robot ini dapat berputar 360 derajat. dengan 2 ban utama yang memiliki gear box dan 2 ban yang bersifat universal yang dapat berputar 360 derajat.

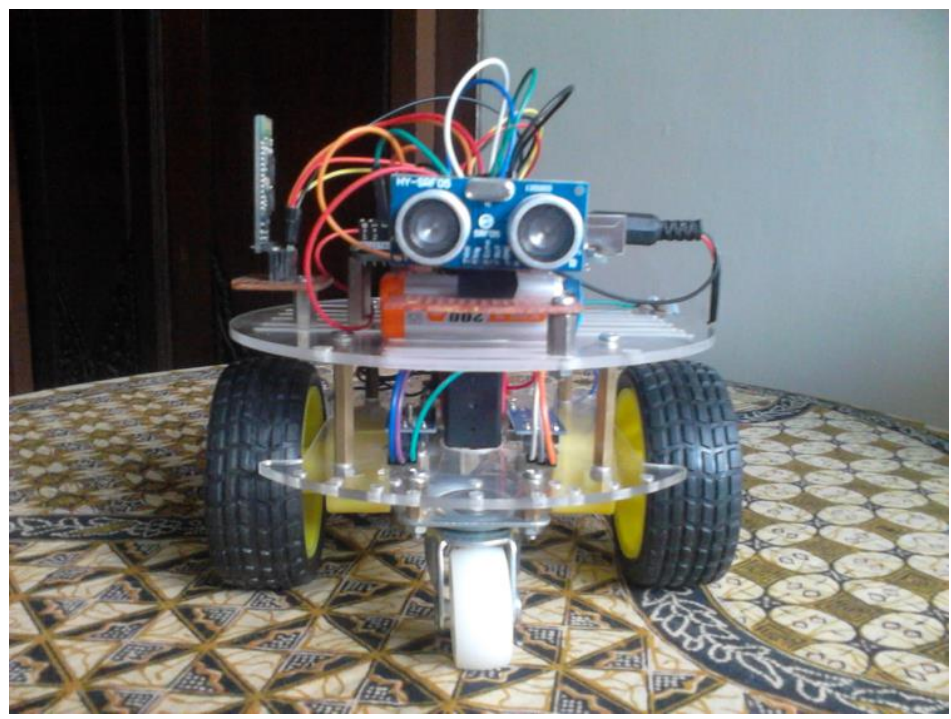

Gambar 2. Desain robot.

Kontrol utamanya yaitu mikrokontroler ATMega 328[4] yang diletakkan di atas bagian robot tersebut. Perangkat lainnya di bagian depan terdiri dari sensor SRF05, di bagian kanan terdiri dari modul bluetooth untuk jalur komunikasi, di bagian dalam robot terdapat driver motor L298 dan photointerrupter.

\subsection{Perancangan Perangkat Lunak}

Untuk merancang trainer robotika, penulis memfokuskan pada perancangan perangkat lunak yang terdapat pada aplikasi trainer robotika yang terdapat pada smartphone android dan perancangan perangkat lunak robot pada mikrokontroler. 


\subsubsection{Perancangan aplikasi diagram alir}

Pada perancangan aplikasi yang terdapat pada smartphone. Di dalam aplikasi tersebut akan terdiri dari enam button yang di antaranya berfungsi untuk mengaktifkan koneksi bluetooth, menonaktifkan koneksi bluetooth, menghubungkan antara smartphone dengan robot, memutuskan jalur komunikasi robot, mengirim data dari smartphone menuju robot, menghapus layout diagram alir dan instruksi robot saat berjalan seperti instruksi untuk berjalan maju, berbelok ke kiri, berbelok ke kanan, mundur, dan saat bertemu dengan rintangan. Sebelum memberikan instruksi.
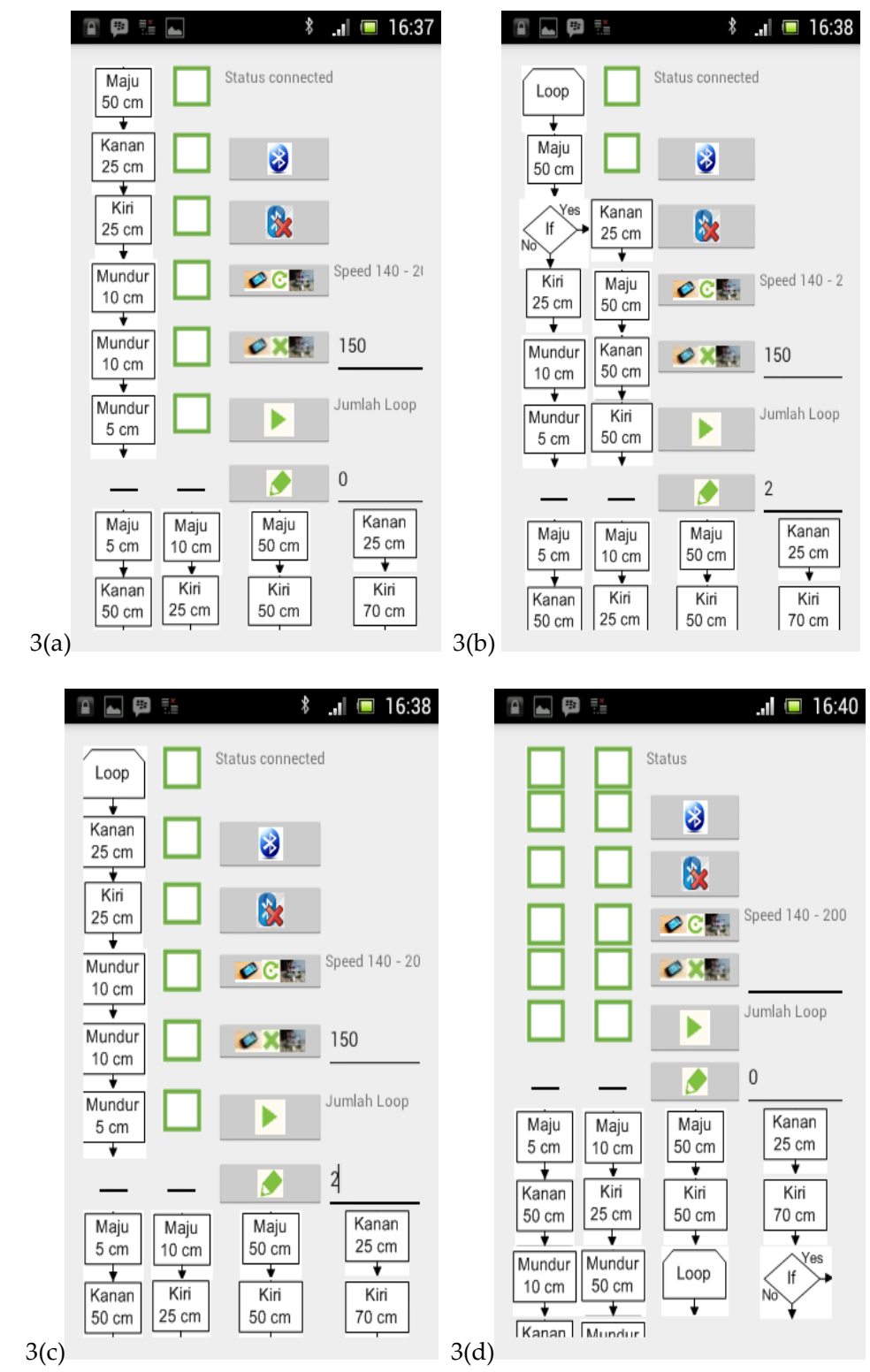

Gambar 3(a) Aplikasi android saat pertama kali diakses. Gambar 3(b) Aplikasi menggunakan instruksi robot berjalan tetapi tanpa instruksi perulangan dan percabangan. Gambar 3(c) Aplikasi menggunakan instruksi robot berjalan, perulangan, dan percabangan. Gambar 3(d) Aplikasi menggunakan instruksi robot berjalan dan perulangan. 
Kemudian flowchart dari aplikasi trainer robotika ditunjukkan pada gambar 4.

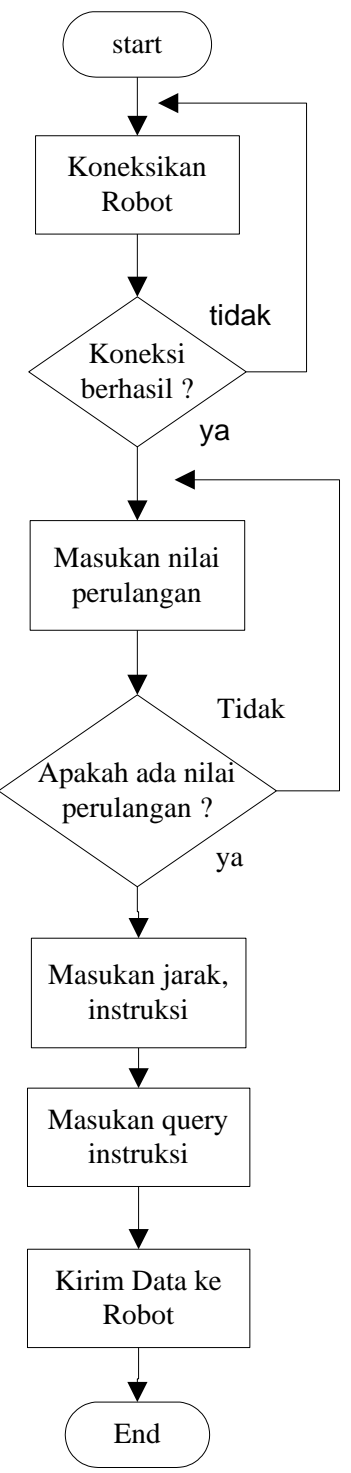

Gambar 4. Diagram alir aplikasi trainer robotika

\subsubsection{Perancangan perangkat lunak Mikrokontroler}

Perancangan perangkat lunak yang ada pada robot merupakan pencangan perangkat mikrokontroler untuk mengakses driver motor, sensor jarak, dan photointerrupter. Tetapi sebelum mikrokontroler mengaktifkan komponen tersebut. Mikrokontroler menunggu data yang masuk melalui dengan melalui komunikasi bluetooth berikut ini akan dijelaskan flowchart dari perangkat lunak pada mikrokontroler. 


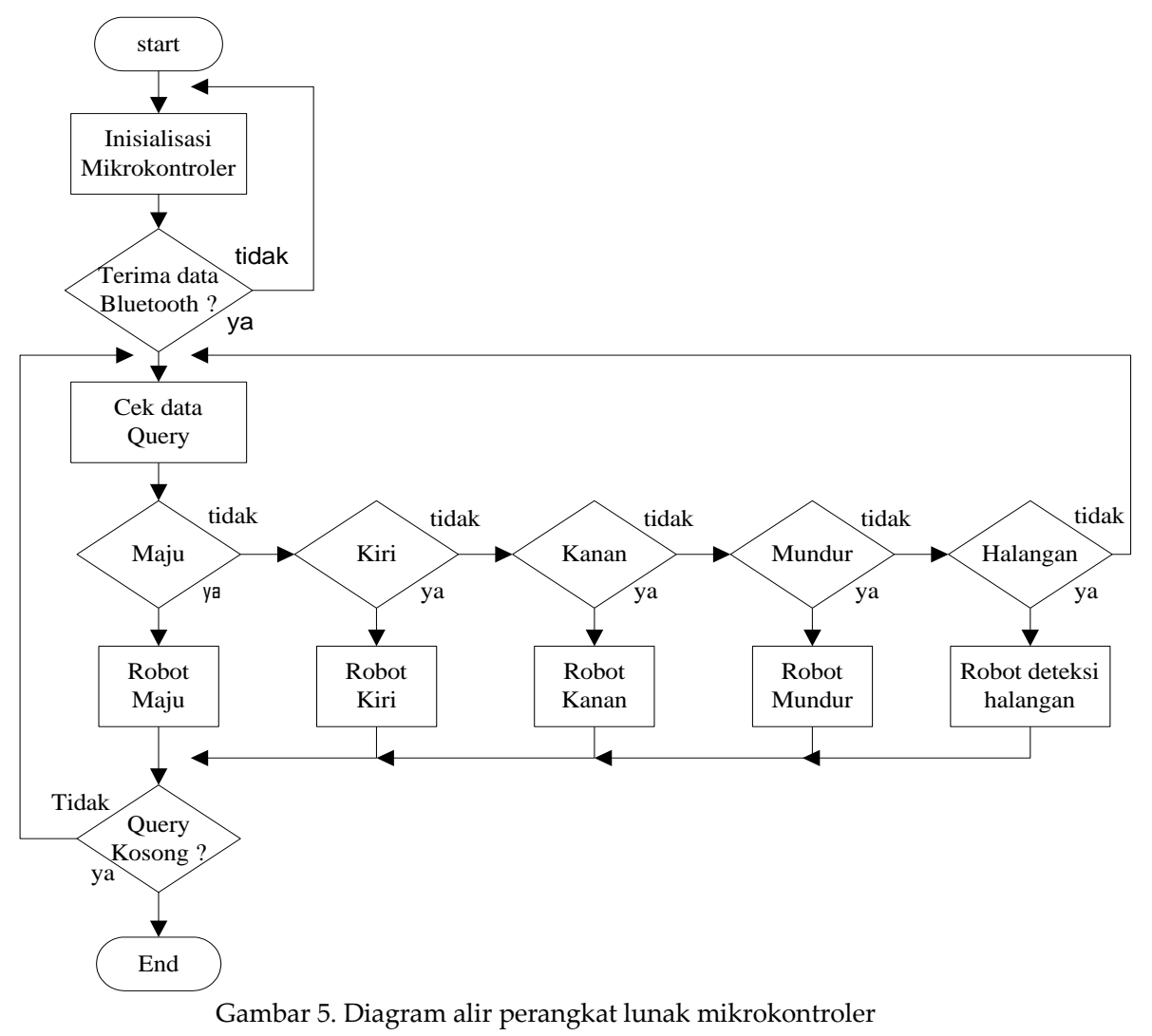

\section{Pengujian dan Pembahasan}

Pada bagian ini dibahas tentang cara pengujian dan hasil pengujian dari alat yang direalisasikan.

\subsection{Pengujian sinkronisasi smartphone dengan robot}

Pada proses ini smartphone melakukan sinkronisasi dengan robot tersebut. yaitu dengan melalui media bluetooth. Pada proses ini akan diuji dengan cara smartphone dengan robot melakukan pairing terlebih dahulu kemudian langkah selanjutnya. Pada aplikasi trainer robotika membuka jalur komunikasi dengan cara mendeteksi Id bluetooth pada modul HC-05 yang ada pada robot. Setelah terdeteksi dan melakukan sinkronisasi. Smartphone dan robot sudah siap berkomunikasi.

\subsection{Pengujian jalan pada robot dengan instruksi dari}

Pada proses ini robot akan menerima instruksi yang diberikan oleh smartphone dengan metode FIFO (First In First Out). Di mana pada metode ini data yang dikirimkan oleh smartphone. Diterima oleh robot tersebut merupakan data yang pertama terlebih dahulu dan akan dikerjakan instruksinya terlebih dahulu. Setelah itu data tersebut dikirimkan melalui bluetooth pada smartphone. Kemudain pada mikrokontroler yang terdapat pada robot nilai data byte tersebut yang akan menjadi tanda untuk robot tersebut berjalan. 
Tabel 1. Banyak Data pengiriman instruksi Robot

\begin{tabular}{|c|c|c|c|c|c|c|c|c|c|}
\hline Maju & $\begin{array}{c}\text { Jarak } \\
\text { robot }\end{array}$ & Kanan & $\begin{array}{c}\text { Jarak } \\
\text { robot }\end{array}$ & Kiri & $\begin{array}{c}\text { Jarak } \\
\text { robot }\end{array}$ & $\begin{array}{c}\text { Mun- } \\
\text { dur }\end{array}$ & $\begin{array}{c}\text { Jarak } \\
\text { robot }\end{array}$ & $\begin{array}{c}\text { Rin- } \\
\text { tangan }\end{array}$ & Stop \\
\hline 0xAA & $\begin{array}{c}\text { 0x00 } \\
\text { sampai } \\
\text { 0x64 }\end{array}$ & 0xBB & $\begin{array}{c}\text { 0x00 } \\
\text { sampai } \\
\text { 0x64 }\end{array}$ & 0xCC & $\begin{array}{c}\text { 0x00 } \\
\text { sampai } \\
\text { 0x64 }\end{array}$ & 0xdd & $\begin{array}{c}\text { 0x00 } \\
\text { sampai } \\
\text { 0x64 }\end{array}$ & 0x80 & 0xEE \\
\hline Halangan & Loop & & & & & & & \\
\hline 0x80 & $\begin{array}{c}\text { 0x03 } \\
\text { sampai } \\
\text { 0x05 }\end{array}$ & $\begin{array}{c}\text { 0x02 } \\
\text { smpai } \\
\text { 0x20 }\end{array}$ & & & & & & & \\
\hline
\end{tabular}

\subsection{Pengujian jarak robot berjalan dalam satuan $\mathrm{cm}$}

Ketika robot menerima data dari smartphone untuk instruksi robot tersebut berjalan. Kemudian mikrokontroler akan mengambil data byte selanjutnya untuk mendapatkan jarak robot tersebut saat berjalan. Seperti pada tabel 1 . Contohnya robot akan berjalan maju maka robot akan menerima instruksi 0xAA setelah itu robot akan mengambil data di array selanjutnya yaitu array setelah instruksi maju. Kemudian nilai tersebut akan menjadi acuan untuk jarak robot tersebut saat berjalan.

Tabel 2. Tabel Pengujian jarak robot saat berjalan

\begin{tabular}{|c|c|c|c|c|c|c|c|c|}
\hline $\begin{array}{l}\text { Jarak } \\
\text { Aktual } \\
(\mathrm{cm})\end{array}$ & $\begin{array}{l}\text { Jarak } \\
\text { Maju } \\
(\mathrm{cm})\end{array}$ & $\begin{array}{c}\text { Selisih } \\
\text { Jarak } \\
(\mathrm{cm}) \\
\end{array}$ & $\begin{array}{l}\text { Jarak } \\
\text { Kanan } \\
(\mathrm{cm})\end{array}$ & $\begin{array}{l}\text { Selisih } \\
\text { Jarak } \\
(\mathrm{cm})\end{array}$ & $\begin{array}{l}\text { Jarak } \\
\text { Kiri } \\
(\mathrm{cm}) \\
\end{array}$ & $\begin{array}{l}\text { Selish } \\
\text { Jarak } \\
(\mathrm{cm}) \\
\end{array}$ & $\begin{array}{l}\text { Jarak } \\
\text { Mundur } \\
(\mathrm{cm})\end{array}$ & $\begin{array}{l}\text { Selisih } \\
\text { Mundur } \\
(\mathrm{cm})\end{array}$ \\
\hline 5 & 5 & 0 & 3 & 2 & 5 & 0 & 5 & 0 \\
\hline 10 & 10 & 0 & 8 & 2 & 10 & 0 & 9.5 & 0.5 \\
\hline 15 & 14.5 & 0.5 & 15 & 0 & 15 & 0 & 14 & 1 \\
\hline 20 & 19 & 1 & 19.5 & 0.5 & 20 & 0 & 19 & 1 \\
\hline 25 & 23.5 & 1.5 & 24.5 & 0.5 & 24 & 1 & 23.5 & 1.5 \\
\hline 30 & 32 & 3 & 30 & 0 & 30 & 0 & 27.5 & 2.5 \\
\hline 35 & 35 & 5 & 33.5 & 1.5 & 33.5 & 1.5 & 32.5 & 2.5 \\
\hline 40 & 38.5 & 1.5 & 39.5 & 0.5 & 40.5 & 4.5 & 38 & 2 \\
\hline 45 & 43.5 & 1.5 & 44 & 1 & 46 & 4 & 42 & 3 \\
\hline 50 & 48 & 2 & 49 & 1 & 49 & 1 & 45.5 & 4.5 \\
\hline 55 & 53.5 & 1.5 & 54.5 & 0.5 & 54.5 & 0.5 & 50 & 5 \\
\hline 60 & 58 & 2 & 58 & 2 & 60 & 0 & 53 & 7 \\
\hline 65 & 63 & 2 & 63.5 & 1.5 & 64 & 1 & 54 & 11 \\
\hline 70 & 67 & 3 & 69 & 1 & 69 & 1 & 60 & 10 \\
\hline 75 & 71 & 4 & 71 & 4 & 75 & 0 & 75 & 0 \\
\hline 80 & 73 & 7 & 73 & 7 & 79.5 & 0.5 & 79.5 & 0.5 \\
\hline 85 & 75 & 10 & 75 & 10 & 85 & 0 & 85 & 0 \\
\hline 90 & 78 & 12 & 78 & 12 & 89 & 1 & 89 & 1 \\
\hline 95 & 82 & 13 & 82 & 13 & 93.5 & 1.5 & 93.5 & 1.5 \\
\hline 100 & 84 & 16 & 84 & 16 & 95.5 & 4.5 & 95.5 & 4.5 \\
\hline \multicolumn{2}{|c|}{ Rata-rata selisih } & 3.8 & & 3.8 & & 1.2 & & 2.9 \\
\hline
\end{tabular}




\subsection{Pengujian trainer robotika kepada siswa-siswi SD sampai SMP}

Pada pengujian trainer robotika kepada siswa-siswi SD sampai dengan SMP. Dilakukan di SD Muhammadiyah Salatiga dan SMP Anak Terang Salatiga. Pengujian dilakukan dengan cara menjelaskan terlebih dahulu tentang penggunaan trainer robotika dan tentang aspek yang terdapat pada trainer tersebut.

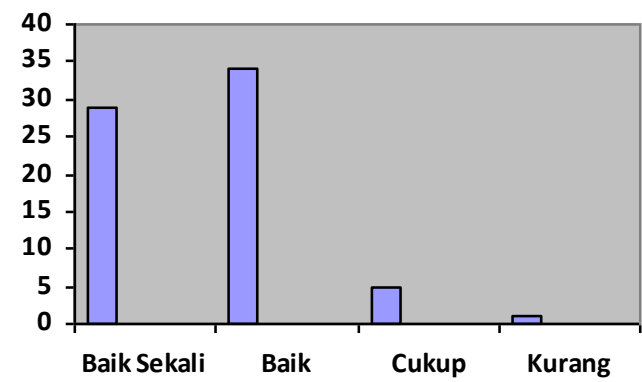

Grafik 1. Hasil kuisioner trainer robotika

Grafik 1 didapatkan dari kuisioner yang dilakukan oleh 7 siswa-siswi SMP dan 3 siswa-siswi SD. Nilai yang didapatkan dari siswa-siswi tersebut dijumlakan untuk setiap pilihan 'Baik Sekali', 'Baik', 'Cukup', dan 'Kurang'. Dapat dilihat bahwa setelah siswasiswi tersebut menggunakan trainer robotika ini mendapatkan respon yang positif dan diharapkan siswa-siswi tersebut memperoleh pembelajaran tentang dasar robotika.

\subsection{Hasil pengujian trainer robotika dalam aspek kognitif, afektif, psikomotor}

a. Aspek Kognitif

- Siswa-siswi SD Muhammadiyah Salatiga kelas 4 saat menggunakan trainer robotika ini.

- Siswa-siswi SMP Anak Terang Salatiga kelas 7 mampu memahami cara kerja dari setiap modul sensor dan akuator yang terdapat pada robot.

b. Aspek Afekif

- Siswa-siswi SD Muhammadiyah Salatiga kelas 4 memilki minat untuk mempelajari apa yang terdapat pada modul trainer robotika ini. Siswa-siswi SMP

- Anak Terang Salatiga kelas 7 antusias dalam menggunakan trainer robotika ini.

c. Aspek Psikomotor

- Siswa-siswi SD Muhammadiyah Salatiga kelas 4 dapat mengikuti prosedur dari langkah-langkah yang harus dilakukan saat menggunakan trainer robotika ini.

- Siswa-siswi SMP Anak Terang Salatiga kelas 7 cepat dalam mengikuti prosedur dari penggunaan trainer robotika. Siswa dapat menyelesaikan masalah jika robot akan berjalan di tempat yang terdapat banyak halangan dengan menggunakan instruksi yang terdapat pada diagram alir. 


\section{Kesimpulan}

Berdasarkan perancangan, perealisasian dan pengujian dapat ditarik kesimpulan sebagai berikut :

1. Pada pengujian sinkronisasi smartphone dengan robot, smartphone dapat melakukan sinkronisasi dengan membutuhkan waktu 1 sampai 2 detik saat melakukan pairing Bluetooth dengan keberhasilan $100 \%$.

2. Pada pengujian instruksi berjalan pada robot. Robot dapat menjalankan perintah yang berasal dari smartphone dengan keberhasilan $100 \%$.

3. Pada pengujian perulangan yang terdapat pada diagram alir. Robot dapat mengikuti instruksi yang diberikan robot dan perulangan berhasil dijalankan dengan keberhasilan $100 \%$.

4. Pembuatan handout trainer robotika yang di dalamnya terdiri dari tutorial pemasangan aplikasi, cara penggunaan aplikasi sampai dengan penjelasan instruksi if, loop, dan instruksi robot berjalan.

5. Hasil kuesioner yang didapatkan dari siswa-siswi SD sampai SMP mendapatkan respon yang baik karena trainer robotika mudah untuk digunakan dan siswasiswi tersebut dapat memahami tentang perulangan robot, percabangan dan instruksi robot sederhana.

\section{Daftar Pustaka}

[1] W. Yohanes, Pembuatan Perangkat Lunak Berbasis Diagram Alir untuk Mengontrol Robot, Universitas Kristen Maranatha, Jawa Barat : Bandung, 2013.

[2] Anonim, Acuan Spesifikasi-XperiaTipo, Sony Xperia Tipo ST21i, [online], www.gsmarena.com, diakses tanggal 24 February 2015.

[3] L298 : Dual Full Brigde Driver, ST Microelectronics, Printed in Italy, 2000.

[4] Anonim, ATMEGA328 Datasheet, [online], Available : www.atmel.com, diakses tanggal 26 Desember 2014. 